\title{
Analysis of Social Factors Financial Services Access Strategy on Farmers Economic Empowerment in Kenya. A case of agricultural Tea Farmer's in Kisii County
}

\author{
Thomas Ombui Nyakweba, Prof. George Gongera, Dr. Irine Koech Asianga
}

\begin{abstract}
The aim of this study was to focus on financial literacy, trainings and gender equity as social factors that influence access to financial services on tea farmer's economic empowerment in Kisii County-Kenya. The study comprised of 77035 small scale tea farmers in Kisii County. Stratified and random sampling was used and the sample size was 398 of the respondents. The study used questionnaires and observations to collect data. Data analysis was done by use of SPSS. The objective of the study was to analyze the influence of social factors on access to financial services strategy on economic empowerment among small scale tea farmers in Kisii CountyKenya. The results show a statistically significant weak positive relationship between social factors on access to financial services and economic empowerment among tea farmers in Kisii County $(r=0.363, p<0.05)$. It was concluded that influence of social factors has positive and statistically significant influence on economic empowerment among tea farmers and there exists a positive significant correlation between influence of social factors and economic empowerment among tea farmers.
\end{abstract}

Index Terms - Financial Access strategy, Finance, Financial Providers, Economic Empowerment, Farmers.

\section{INTRODUCTION}

Financial literacy means having the knowledge, skills and confidence to make responsible financial decisions. OECD (2005), defines financial literacy as the combination of consumers'/investors' understanding of financial products and concepts and their ability and confidence to appreciate financial risks and opportunities, to make informed choices, to know where to go for help, and to take other effective actions to improve their financial well-being.

In Kisii County, over $80 \%$ of the population depends on agriculture for their livelihood - both as a source of food as well as income. Access to financial literacy is one of the key challenges facing farmers in Kisii county, hence the reason why financial accessibility strategy is vital on education and training to the farmers to enable them to make proactive decisions and learn ways to plan and control household and

Thomas Ombui Nyakweba, Kabarak University, School Of Business and Economics, Kenya

Prof. George Gongera, Cooperative University, Kenya

Dr. Irine Koech Asianga, Kabarak University, School Of Business and Economics, Kenya business finances for their economic empowerment. However, according to the (World Bank, 2015), the average age of farmers around the world is rising as agriculture is not appealing to young people. Women in agriculture do not have the same access to technology, finance and extension as men do, which results in lower yields and income.

According to (Omunjalu and Fondo, 2014) in their study on microfinance and the youth empowerment concluded that microfinance influenced economic status, decision making power and knowledge hence was effective for the poor youth and middle class to rise to higher living standards. Osmani (2007) described how poor women can be empowered through participation in microcredit programs. This/ has not been achieved in Kisii County specifically to tea farmers who are the majority in the county and were the units of the study.

\section{A. Significance of the study}

The study focused on financial access strategies that were to empower tea farmers economically to raise their standard of living by accessing financial services from financial providers. It was to provide a clear distinction between standard of living and quality of life variables in measuring the economic situation of tea growers. This was to provide better understanding and clarity to the implication of the findings for comparison by future studies; and its outcome will be useful as reference materials for government, development agencies and other publics in the provision of financial services to tea farmers. The research was expected to deepen the understanding of the challenges and opportunities of communities living and working in the tea sector so that ways were to be found to address the issues in the short and long term basis.

\section{LITERATURE REVIEW}

This strategy addresses gaps in financial literacy; with a view to enhancing Tea farmers in making informed financial decisions about managing and protecting their financial affairs.

Financial literacy means having the knowledge, skills and confidence to make responsible financial decisions. OECD (2005), defines financial literacy as the combination of consumers'/investors' understanding of financial products and concepts and their ability and confidence to appreciate 
financial risks and opportunities, to make informed choices, to know where to go for help, and to take other effective actions to improve their financial well-being. Miller et al.(2009,) Kevin (2014)it aims to collaborate the efforts of public, private and non-profit sector organizations to improve farmers' financial literacy levels, to provide support for their financial decision-making, and over time, to contribute to their financial well-being.

The education units of time are therefore transformed and expressed as the human capital stock value in terms of money (Wößmann, 2003). In this thesis, the income-based approach is utilized to compute small scale tea farmers household human capital based on the individual earnings that are also influenced by acquired skills and education level. A study by Zuze (2014), observed that poor saving culture among the tea farmers was due to low literacy levels, poor funds management and low income levels among other contributing factors.

Based on the above literature, in Kisii County, tea farmer's majority of them are illiterate or semi literate, unable to make sound decisions on financial management matters despite monthly payments on the ground they are financially weak.

Mwongera (2013) described financial literacy as the ability to have appropriate book keeping skills and financial management skills. Meeme (2013) argued that education on small holder farmers is of paramount importance. She argues that better equipped farmers with financial skills will be better placed to form trusting relationships with sales banking institution. Mamun et al. (2010) in his study found out that the followers of Grameen Bank group used micro credit model to provide training in order to improve microenterprises management skills to enable their clients to take advantage of income and employment generating opportunities. While mistakes in making personal finance decisions is considered real, the study argued that lack of knowledge about key personal finance issues contributes to these mistakes, calling for knowledge acquisition to counter this, hence empowering the tea farmers. Capacity building Observations and interviews indicated that only people in high position such like accountants, managers and agricultural advisers are considered for in service training. Implying smallholder tea growers are not considered for capacity building on how to be empowered from tea proceeds.

"Financial literacy will economically empower farmers to save, invest and diversify their income streams and make tea farming a sustainable business," said KTDA chief executive LerionkaTiampati (TBK, 2017). According to (KTDA, 2015), improved financial literacy will help farmers to manage the farms, income, improve productivity per bush and establish alternative income streams. "Given the current challenges leading to decreased productivity for most crops, it is critical that farmers are able to wisely manage the money received from tea as well as be guided to make decisions on other sources of income, " says Jane Onoka(IFC,2015).

Financial service access strategy is vital for tea farmer's economic empowerment through trainings to tea farmers in Kisii county ,since majority of the farmers are inadequately trained on how to use the meager financial resource such as, paying fees for their children, building and even buying household items. However according to (Beijing and Beyond, 2004), training enables women and men to access capital and to expand their own income generating micro-enterprises which, in turn, will expand household income.

A study conducted by (Aker, 2010), recommended that the training of the extension workers should include computer literacy to enable them access to internet and other electronic information technologies. Farmers require electronic information to access information on modern farming and finance to understand a wider range of opportunities available in the financial market. According to(Anderson etal., 2007),the majority of poor households in developing countries rely on subsistence agriculture for their own food production and as a source of income.

FFSs are currently one of the most common approaches to rural adult education and agricultural extension and have reached an estimated 10-20 million people in over 90 countries (Waddington et al. 2014; Waddington, H., B.Snilstveit, J.Hombrados, M.Vojtkova, D. Phillips, P. Davies, and H. White. 2014). However, early adopters of innovative agricultural techniques are often better-off farmers who are more able and more likely to accept the risk that any new method implies, as they have access to the necessary assets, the ability to absorb the costs of additional labor time and are comparatively better able to withstand a negative shock should it occur.

Financial access strategy is critical for youths and women empowerment in Kisii County and need to make agriculture more attractive is crucial so that they can contribute more to county development to achieve vision 2030 food security for all. According to (UN, 2009), Women access to and control over economic resources is critical for the achievement of gender equality and empowerment of women as well as for equitable and sustainable economic growth. The study by (Kiplangat, 2014) asserted that through income generating activities funded by the government and financial institutions, women acquired the assets but did not have a proper way of keeping financial records. Kibas(2006) puts it, lack of opportunities for management training, financial management and People management has hampered women and their organizations from effectively engaging on enterprise development.

However, according to the (World Bank, 2015), the average age of farmers around the world is rising as agriculture is not appealing to young people. Women in agriculture do not have the same access to technology, finance and extension as men do, which results in lower yields and income. According to (Omunjalu and Fondo, 2014) in their study on microfinance and the youth empowerment concluded that microfinance influenced economic status, decision making power and knowledge hence was effective for the poor youth and middle class to rise to higher living standards. Osmani (2007) described how poor women can be empowered through participation in microcredit programs. First, microcredit enables poor women to earn an Independent income and contribute financially to their 
World Journal of Innovative Research (WJIR)

ISSN: 2454-8236, Volume-5, Issue-3, September 2018 Pages 12-17

families, which immediately raises their self-esteem as well as their esteem in the eyes of others.

The Kenyan government has recognized the marginalization of rural women and the pressing issue of gender inequalities on a national level and attempted to tackle these by adopting a National Commission on Gender and Development in 2004, along with 'Gender Desks' across many of its ministries(Ellis et al., 2007). According to World Bank (2001), promoting women's empowerment is essential because in most cases women are responsible for their children and for their family, thus empowering women is empowering the society at large. Improving women's direct access to financial resources in Kisii County will result in higher investments in human capital and have a stronger impact on their children's health, nutrition and education.

\section{RESEARCH METHODOLOGY}

The research is expected to describe the variables in a situation of interest to the researcher. Thus this study is descriptive in nature. Descriptive study is appropriate because the nature of the problem was well known and the objective is clearly specified, Kothari (2004).In this study, the target population comprised of 77035 small scale tea farmers in Kisii County. Using Yemane (1967) formula, the researcher has a sample size of 398 respondents distributed as under:

Table 1: Distribution of respondents

\begin{tabular}{|c|c|c|c|c|}
\hline $\begin{array}{r}\text { Target Population } \\
\text { Category }\end{array}$ & Constituency & $\begin{array}{c}\text { Target } \\
\text { Population }\end{array}$ & $\begin{array}{l}\text { Sample } \\
\text { Size }\end{array}$ & $\begin{array}{l}\text { Selection } \\
\text { Method }\end{array}$ \\
\hline \multirow[t]{2}{*}{$\begin{array}{l}\text { Nyamache Factory } \\
\text { main } \\
\text { Nyamche } \\
\text { branch-Itumbe }\end{array}$} & \multirow[t]{2}{*}{ Bobasi } & 16454 & 85 & $\begin{array}{l}\text { Randomly } \\
\text { selected }\end{array}$ \\
\hline & & 12409 & 64 & $\begin{array}{l}\text { Randomly } \\
\text { selected }\end{array}$ \\
\hline \multirow{2}{*}{$\begin{array}{l}\text { Ogembo } \\
\text { factory } \\
\text { Ogembo } \\
\text { branch-Eberege }\end{array}$} & \multirow{2}{*}{$\begin{array}{l}\text { MachogechacheMachogeborabu } \\
\text { South mugirango } \\
\text { Bonchari }\end{array}$} & 15854 & 81.9 & $\begin{array}{l}\text { Randomly } \\
\text { selected }\end{array}$ \\
\hline & & 11805 & 60.99 & $\begin{array}{l}\text { Randomly } \\
\text { selected }\end{array}$ \\
\hline \multirow{2}{*}{$\begin{array}{l}\text { Kiamokama main } \\
\text { factory } \\
\text { Branch-Rianyamwa } \\
\text { mu }\end{array}$} & \multirow[t]{2}{*}{$\begin{array}{l}\text { Nyaribarimasaba } \\
\text { Nyaribarichache }\end{array}$} & 12176 & 60.907 & $\begin{array}{l}\text { Randomly } \\
\text { selected }\end{array}$ \\
\hline & & 8337 & 43.07 & $\begin{array}{l}\text { Randomly } \\
\text { selected }\end{array}$ \\
\hline Total & & 77035 & 398 & \\
\hline
\end{tabular}

Source: (Researcher, 2018)

In this study, the researcher employed stratified sampling and simple random sampling techniques. Observation and questionnaires were used in data collection. Data collected was analyzed in tabulated form with the aid of simple percentages, tables, bar graphs and pie charts.

\section{A. Data Analysis}

The researcher distributed a total of 398 questionnaires to the respondents out of which 269 were correctly filled and returned back. This represented response rate of $67.6 \%$. According to Babbie (1990), a response rate of $60 \%$ is good, $70 \%$ very good and $50 \%$ adequate for analysis and reporting from manual surveys. Thus the response rate was deemed sufficient for further analysis of the research objectives.

\section{FINDINGS AND DISCUSSIONS}

When respondents were asked how much they earn from tea farming,majority of them indicated that $14.5 \%$ earned below 500, 22.7\% earned Ksh501-1000, 20.8\% earned Ksh 1001-1500, 27.5\% earned Ksh 1500-2000, 7.4\% earned Ksh2001-2500, $5.9 \%$ earned Ksh2501-3000 while only 1.1\% earned above Ksh3000 per month from tea farming in Kisii County. This implies that there has been an increase in respondents who have been earning increased income along income categories. Thus the respondents were well versed with the topic under study on financial services access. However, it was noted that those earning 
ksh.1500-2000 do not depend on their tea farms alone but also pick tea leaves from hired land.

\section{A. Factor Analysis on social factors}

Principal component analysis extraction method with varimax rotation method was used; and validity was assessed by examining the factor loadings to see if the items in the scale loaded highly on the construct. Table2 presents the results of the analysis for the number of items that had significant loading on each component factor after varimax rotation.

Table 2: Rotated Component Matrix for Measures of Social factors

\section{Social factors items \\ Component \\ 1}

a) Educational level of tea farmers determines their financial accessibility for economic empowerment

b) Knowledge and experience of tea farmers in Kisii county enables them to access financial services for their economic empowerment

c) Financial literacy is key to financial accessibility for tea farmers economic empowerment in Kisii county

d) Training of tea farmers in financial management is key to financial accessibility for their economic empowerment

e) Farm field schools boost financial accessibility to tea farmers for economic empowerment

f) Gender equity to financial resources hinders financial accessibility by tea farmers in kisii county for their economic empowerment

g) Illiteracy among women tea farmers in kisii county hinders financial accessibility for their economic empowerment

h)Women access to financial services promotes economic empowerment to tea farmers in kisii county

i) Gender involvement in decision making leads to financial accessibility among tea farmers in kisii for their economic empowerment

j) Equal rights to property ownership enhances financial accessibility by tea farmers in kisii county for their economic empowerment
.519

23

Extraction Method: Principal Component Analysis.

Rotation Method: Varimax with Kaiser Normalization.

\section{Source: (Researcher, 2018)}

The rotated component matrix in Table 2 shows that all the factor loadings of social factors items ranged from 0.519 to 0.898 . All the ten items met loading cut off of 0.4 and were thus retained for analysis. A maximum of four factors were obtained, the four initial factors had Eigen values greater than 1 and their extraction sums of squared loadings were greater than 1. Factor 1 had the highest extraction sums of squared loadings of 2.748, representing 27.479 percent of variance. Factor 4 had the least extraction sums of squared loadings of 10.018 which represent 10.182 percent of variance. Other factors extraction sums of squared loadings were between the range of 2.748 and 0.408 . The contributing power of these other factors to the explanation of the variance in the variables was considered very significant. 
World Journal of Innovative Research (WJIR)

ISSN: 2454-8236, Volume-5, Issue-3, September 2018 Pages 12-17

\section{SUMMARY, CONCLUSIONS AND RECOMMENDATIONS}

This study sought to examine the influence of financial services accessibility on economic empowerment among small scale tea farmers in Kisii County, Kenya. Data for the study was collected using structured questionnaires from 269 respondents in Kisii County. Descriptive and inferential statistics were used to summarize and analyze the data. The response rate was $67.6 \%$.

This section summarizes the research findings of the study on the basis of formulated research objectives and hypotheses.

\section{A. Influence of social factors on economic empowerment among tea farmers}

The study sought to assess influence of social factors on economic empowerment among tea farmers in Kisii County. According to the research findings, educational level determines farmers financial accessibility; due to the nature of neutrality among the respondents, it was not clear whether knowledge and experience enables tea farmers access financial services and whether training of tea farmers on financial management was key to financial accessibility. Respondents agreed that financial literacy was significant in enhancing financial accessibility among tea farmers. Farm field schools do not boost financial accessibility among tea farmers while it was not clear among respondents on whether gender equity to financial resources hinders financial accessibility among tea farmers due to neutrality in responses Illiteracy among women hinders financial accessibility with women access to financial services promoting economic empowerment among tea farmers. Respondents were neutral on whether gender involvement in decision making leads to financial accessibility and whether equal rights to property ownership enhances financial accessibility among tea farmers in kisii County. There exist statistically significant, positive relationships between social factors and economic empowerment among tea farmers in Kisii County, according to the coefficient results of the individual regression model. Moreover there exists a weak, positive significant correlation between social factors and economic empowerment among tea farmers.

\section{CONCLUSIONS}

Based on the research findings of the study, the following conclusions were drawn.

It was concluded that influence of social factors has positive statistically significant influence on economic empowerment among tea farmers. There exists a positive significant correlation between influence of social factors and economic empowerment among tea farmers in Kisii County, Kenya. Further, conclusions can be made that educational level determines tea farmers financial accessibility this is because when tea farmers are educated, they are able to process financial market information relating to financial inclusion. Moreover, financial literacy is a significant factor in enhancing financial accessibility among tea farmers. Illiteracy among women hinders financial accessibility with women access to financial services promoting economic empowerment among tea farmers. When women literacy level increases, they are able to process information of financial nature relating to borrowing, investing and credit management.

\section{A. Recommendations for Policy}

Based on the research findings and conclusions, the following recommendations were made;

It was recommended that national and county government should roll out programs in conjunction with KTDA carry out financial education. This will aggravate the uptake of financial services for investment purposes among tea farmers in a bid to improve their economic welfare. It was recommended that through collaboration between KTDA and financial institutions tea farmers should regularly organize workshops trainings on financial literacy to create awareness on financial management and opportunities on their economic empowerment.

\section{B. Contribution of Study to Knowledge}

The study shed light on how financial resources help rural communities function, how their relationships develop, how individual esteem is increased, their interdependence grows, and how this is facilitated in part by the loan-making of members promoted financial providers. It further provided more evidence on the importance of land ownership, and how this is enhanced when rural communities have access to cheap and affordable loans. It has also provided insights into the development of rural businesses, how complex they are, and how they require more input than the financing received through financial providers' loans. In this way, the study makes a significant contribution to our understanding of rural communities in developing economies, thereby allowing the relationship between financial service access strategies and economic empowerment among small scale tea farmers to be made clearer. In this way, the contribution is both academic in addition to the literature on county development, rural finance, standard of living issues, informal and formal financial functioning, and to practice - in the application of the findings to policy development, specifically in the financial sector.

The study provides a clear distinction between standard of living and quality of life variables in measuring the economic condition of farmers and, it helps to trace the role of financial access strategy by farmers to ownership of household assets, enterprise assets, enterprise profitability and increase in household income to determine changes in members' standard of living. This is important, because it enhances our understanding of the role of financial access in improving standards of living of the small scale tea farmers rather than quality of life such as health and family planning which financial institutions may not be financially adequately is empowered to do.

The study has made a contribution in the application of financial theories in exploring the financial strategies in the creation of the five components -level of financial providers, physical proximity, economical factors- of the theory for small scale tea farmers.

This study contributes to knowledge by filling the gap 
identified in the literature on access to financial service strategies among small scale tea farmers. The objectives critically examined the financial access strategies on tea farmers' standard of living. However, the role of financial access strategies among small scale tea farmers on economic empowerment has not been studied in any systematic way. This study fills the gap by examining the main criteria of standard of living at the individual, household and enterprise levels which are not explicit in other studies. The gap was filled in the sense that the study engaged the literature in identifying the limitations of previous studies. Methodologically, the study began by considering the range of other researchers' methods, which include research strategies suitable for the study, and also identified users of these methods and the reasons for their choices. This process led to the choice of both qualitative method for the study through an organized system of data collection.

This study also contributes to knowledge by applying the financial deepening, inclusive information asymmetry theories to all the five research objectives, so as to discover the contribution of financial accessibility strategies to small scale tea farmers' standard of living and its implication for economic empowerment. The uniqueness of this study is the application of financial service accessibility strategies in Kisii County with concentration on small scale tea farmers economic empowerment. This not only enables us to understand more fully how financial access benefits flow from providers in Kisii county but, allows a more general statement of the effect of rural finance provision to the improvement of tea farmers' standard of living.

\section{Recommendations for Further Research}

The study employed a case study approach of Kisii County; it is recommended that this study be carried on a broader scale in Kenya. Yin (2003) asserts that a single case study findings cannot be generalized in compared to multiple case study. In determination of measurable indicators under each variable of the study qualitative research was used. The study employed a case study approach of Kisii County; it is recommended that this study be carried on a broader scale in Kenya.. The study recommends further research to test and validate the research findings using a quantitative approach.

\section{REFERENCES}

[1] Aker, J.C. (2010). Dial "A" for Agriculture: Using Information and Communication Technologies for Agricultural Extension in Developing Countries, (online) Available at http://www.cgdev.org

[2] Anderson and Feder,(2007) J.R.Agricultural extension Handbook of agricultural economics,Agricultural development: Farmers, farm production and farm markets, Vol.3pp. 2343-2378Available at http://www.cgdev.org

[3] Babbie, E. (2001). The Practice of Social Research. Wadsworth publishing company, Belmont, California.

[4] Braun, A. \& Duveskog, D.(2010). The Farmer Field School ApproachHistory Global Assessment and Success Stories. Background paper for IFAD Rural Poverty Report

[5] Campbell, J.Y. (2006). Household Finance. National Bureau of Economic Research. Retrieved from http:// papers.nber.org

[6] Cronbach, L. (1951). Coefficient alpha and the internal structure of tests"..kttm.hoasen.edu.

[7] Kibas, P. B. (2006). Women in entrepreneurship: Analysis of factors influencing growth-oriented women entrepreneurs in rural Kenya, paper presented at the 3rd International Entrepreneurship Conference organized by United States International University (USIU), Nairobi. Retrieved from http://ejobm.org

[8] Kiplangat B. k.(2014) Contribution of Women Groups in the Economic Empowerment of Rural Women: A Case of Women Groups in Bureti Constituency, Kerich County, Kenya-University of Nairobi

[9] Kothari, C. R. (2004). "Research Methodology: Methods and Techniques," ( $2^{\text {nd }}$ Edition). New Delhi: New Age International $(\mathrm{P})$ Ltd.

[10] Mamum, A., Wahab, S. \& Malarrizhi, C.A. (2010). Examining the effect of Access to credit on employment in Peninsular Malaysia. Journal of Sustainable development , 4(2).

[11] Meeme, B. M. (2013). Factors influencing Access to formal credit by small scale women tea farmers in Kenya: A case of Thika District, Kiambu County. University of Nairobi.

[12] Miller, M., Godfrey, N., Levesque, B. \&Stark, E.(2009).the case for Financial Literacy in Developing countries: Promoting Access to Finance by Empowering Consumers.

[13] Mwongera, R. K. (2014). Factors influencing access to microfinance credit by young women enterprenuers projects in Athi- River, Kiambu County, Kenya. University of Nairobi.

[14] OECD (2005).Improving Financial Literacy :Analysis of Issues and OECD Policies Paris: OECD Publishing .

[15] Omunjalu, B.S. \&Fondo, F. (2014). The role of microfinance in economic empowerment on employment in Peninsular Malaysia. Journal of Sustainable development, 4(2).

[16] Osmani,L.N.K.(2007). A breakthrough in women's bargaining power: the impact of microcredit. Journal of international Development, 19, 695-716. Othaya division, Nyeri County

[17] Tea Research Foundation of Kenya (TRFK). (2011). Strategic Plan 2010-2015. http://www. www.tearesearch.or.ke

[18] UN (2009). 2009 World Survey on the Role of Women in Development: Women's Control over Economic Resources and Access to Financial Resources, including Microfinance. New York. Retrieved from http://www.un.org

[19] Waddington, H and White, H, 2014. Farmer field schools: from agricultural extension to adult education, 3ie Systematic Review Summary 1. London: International Initiative for Impact Evaluation (3ie).

[20] Waddington, H., B. Snilstveit, J. Hombrados, M.Vojtkova, D. Phillips, $\begin{array}{ll}\text { P. Davies, and H. White. 2014. "Farmer Field Schools for } & \end{array}$ Improving Farming Practices and Farmer Outcomes: A Systematic Review." Campbell Systematic Reviews. http://campbellcollaboration.org

[21] World Bank, (2001).Gender equality and the millennium development goals. Gender and Development Group. World Bank.

[22] World Bank,( 2014). Financial Inclusions.Global Financial Development Report. Pp. 1-105.

[23] Wößmann, L. (2003). Specifying Human Capital. Journal of Economic Surveys, 17 (3): 239- 270.

[24] Yamane, T. (1967).Statistics, An Introductory Analysis. Harper and Row. New York.

[25] Yin, R. (2003). Case study research. Thousand Oaks, Calif.: Sage Publications.

[26] Zuze, B. S.( 2014) Factors that influence savings of small scale tea farmers in Kericho town- Kenya, University of Nairobi. 